\title{
Analisis Yuridis Normatif dan Hukum Islam \\ Terhadap Putusan Mahkamah Konstitusi Nomor 30-74/PUU-XII/2014 Tentang Batas Usia Perkawinan Anak (Perempuan)
}

\author{
Hasanain Haikal \\ Dosen STAIN Kudus \\ ical.hasanain@gmail.com
}

\begin{abstract}
Islam knows no age limits, the foundation in this case is strong enough for the Prophet of Islam himself married Siti Aisyah at the age of 6 years. so from the point of view of Islamic law looks no gap. but Islam does not stress if the condition is in a state of emergency can be changed law will follow the situation. The Court rejected the applicant's judicial review, the Court assesses the applicant's argument is groundless and rejected applicants for all. Judges consider that the need for an age limit for women in particular adapted to many aspects, such as health, social, cultural, and economic. In fact, there is no guarantee an increase in the age limit for women to marry from 15 to 18 years would reduce the divorce rate, tackling health problems, as well as other social issues. To prevent child marriage is a big issue, according to the Court not only by the limitations of age alone. There is a possibility, if it is based on various aspects of the development of social economy, culture, and technology, 18 years of age can be lower or even higher.
\end{abstract}

Keywords: Constitutional Court, the age of marriage, Islam

\begin{abstract}
ABSTRAK
Islam tidak mengenal batasan umur, landasan dalam hal ini cukup kuat karena Rosul Saw sendiri menikahi Siti Aisyah pada usia 6 tahun. sehingga dari sudut pandang hukum Islam terlihat tidak ada celah. akan tetapi Islam tidak kaku jika memang kondisinya memang dalam keadaan darurat bisa jadi hukum akan berubah mengikuti keadaan. MK menolak gugatan pemohon uji materi, MK menilai dalil pemohon tidak beralasan, dan menyatakan menolak permohonan pemohon untuk seluruhnya. Hakim menimbang bahwa kebutuhan batas usia khususnya bagi perempuan disesuaikan dengan banyak aspek, seperti kesehatan, sosial, budaya, dan ekonomi. Bahkan, tidak ada jaminan kenaikkan batas usia kawin bagi perempuan dari 15 menjadi 18 tahun akan mengurangi angka perceraian, menanggulangi permasalahan kesehatan, maupun persoalan sosial lainnya. Untuk mencegah perkawinan anak yang banyak menimbulkan masalah, menurut MK tidak hanya dengan batasan usia semata. Tidak tertutup kemungkinan, jika didasarkan pada berbagai perkembangan aspek sosial ekonomi, budaya, dan teknologi, usia 18 tahun bisa dianggap lebih rendah atau malah lebih tinggi.
\end{abstract}

Kata kunci : Mahkamah Konstitusi, Usia Perkawinan, Islam

\section{A. Pendahuluan}

Perkawinan adalah hak setiap orang yang harus dijamin dan dilindungi oleh negara karena perkawinan merupakan hak yang bersifat asasi dan naluriah kemanusiaan yang melekat pada diri setiap orang dan sesuatu yang kodrati. Sesuai dengan falsafah pancasila dan untuk pembinaan hukum secara nasional maka negara membentuk
Undang-Undang Perkawinan yang berlaku bagi semua warga negara. ${ }^{1}$ Secara hukum alam, perkawinan adalah kebutuhan yang tidak dapat

1 Yoga Anggoro, 2007, Undang-Undang Perkawinan Nomor 1 Tahun 1974 dan Undang-Undang 23 Tahun 2004 Tentang Penghapusan Kekerasan dalam Rumah Tangga, Transmedia Pustaka, Jakarta, hal. 1. 
dihalangi oleh siapapun selama perkawinan tersebut dilaksanakan menurut kaedah agama dan hukum negara yang berlaku. Perkawinan merupakan peristiwa penting dalam kehidupan manusia yang dibentuk oleh unsur-unsur alami dari kehidupan manusia itu sendiri yang meliputi kebutuhan fungsi biologis, melahirkan keturunan, dan kebutuhan kasih sayang serta pengangkatan status bagi laki-laki dan perempuan. Perkawinan juga mengandung makna membolehkan hubungan kelamin antara laki-laki dan perempuan secara sah yang akhirnya memunculkan hak dan kewajiban kepada suami dan istri.

Perkawinan dalam perspektif agama, seperti Islam, perkawinan merupakan salah satu anjuran bagi siapapun yang sudah dewasa dan punya kemampuan untuk berkeluarga supaya menikah untuk menenangkan hati, jiwa, dan raga, serta untuk melanjutkan keturunan dalam membentuk keluarga yang bahagia. Ajaran Islam mendorong umatnya, khususnya kaum mudanya, untuk segera melakukan pernikahan.

Hukum perkawinan di Indonesia dikodifikasikan dalam Undang-Undang Perkawinan Nomor 1 Tahun 1974 (UU Perkawinan). Undangundang ini merupakan kompromi antara hukum negara dan agama Islam. Kriteria umur dalam undang-undang tersebut dinyatakan melalui Pasal 7 ayat (1) dan ayat (2), yang berbunyi : (1) Perkawinan hanya diizinkan jika pihak pria sudah mencapai umur 19 (sembilan belas) tahun dan pihak wanita sudah mencapai umur 16 (enam belas) tahun. (2) Dalam hal penyimpangan terhadap ayat (1) pasal ini dapat meminta dispensasi kepada pengadilan atau pejabat lain yang ditunjuk oleh kedua orang tua pihak pria maupun pihak wanita.

Oleh beberapa kalangan, kelompok masyarakat tertentu isi Pasal 7 ayat (1) dan, (2) diatas dianggap bertentangan dengan UUD 1945. Mereka kemudian mengajukan uji materi UndangUndang Perkawinan terhadap UUD 1945 yang perkaranya dalam sidang Mahkamah Konstitusi diberi nomor 30 dan 74/PUU-XII/2014 tentang Batas Usia Perkawinan Anak (Perempuan). Perkara nomor 30 dan 74 mempunyai objek perkara yang sama sehingga MK memututus perkara tersebut secara bersamaan. Para Pemohon mengganggap bahwa UndangUndang Perkawinan pasal 7 ayat (1) dan ayat (2) bertentangan dengan UUD 1945. Sehingga penulis melalui makalah ini, bermaksud untuk menganalisa aspek-aspek legal formal yuridis normatif pengambilan keputusan oleh Mahkamah Konstitusi dan pandangan dari Hukum Islam mengenai usia perkawinan.

\section{B. Pembahasan}

\section{Analisis Yuridis Normatif terhadap} Putusan Mahkamah Konstitusi Nomor 30-74/PUU-XII/2014 tentang Batas Usia Perkawinan Anak (Perempuan)

Mahkamah Konstitusi (MK) dalam amar putusannya mengadili dan menyatakan menolak permohonan para Pemohon untuk seluruhnya. ${ }^{2}$ Perkawinan dalam pelaksanaannya berkaitan erat dengan keyakinan yang sakral berdasarkan kaidah dan nilai-nilai suci agama yang tidak dapat diabaikan. Hal ini sebagaimana ditegaskan dalam Pasal 28B ayat (1) UUD 1945 yang menyatakan, "Setiap orang berhak membentuk keluarga dan melanjutkan keturunan melalui perkawinan yang sah." Pemahaman perkawinan yang sah tersebut harus dilihat dari dua aspek yakni sah menurut hukum agama dan sah menurut hukum negara; Semua agama yang berlaku di Indonesia memiliki aturan masing-masing dalam perkawinan dan hukum agama tersebut mengikat semua pemeluknya, sedangkan negara memberikan pelayanan dalam pelaksanaan perkawinan dengan aturan negara termasuk pencatatan secara administrasi guna kepastian hukum bagi pasangan suami istri maupun keturunannya. Hal ini sebagaimana diatur dalam Pasal 2 ayat (1) UU Perkawinan yang menyatakan, "Perkawinan adalah sah apabila dilakukan menurut hukum masing-masing agamanya dan kepercayaannya itu." dan Pasal 2 ayat (2) UU Perkawinan menyatakan, "tiap-tiap perkawinan dicatat menurut peraturan perundang-undangan yang berlaku.";

Para Pemohon pada pokoknya mendalilkan Pasal 7 ayat (1) sepanjang frasa "16 (enam belas) tahun" UU Perkawinan bertentangan dengan

2 Putusan Mahkamah Konstitusi Nomor 30-74/ PUU-XII/2014, hal 233-234. 
Pasal 1 ayat (3), Pasal 28A, Pasal 28B ayat (1), Pasal 28B ayat (2), Pasal $28 \mathrm{C}$ ayat (1), Pasal $28 \mathrm{D}$ ayat (1), Pasal $28 \mathrm{G}$ ayat (1), Pasal $28 \mathrm{H}$ ayat (1), Pasal $28 \mathrm{H}$ ayat (2), Pasal $28 \mathrm{I}$ ayat (1), dan Pasal 28I ayat (2) UUD 1945;

Dewan Perwakilan Rakyat (DPR) dalam sidang perkara Nomor 30-74/PUU-XII/2014 tentang Batas Usia Perkawinan Anak (Perempuan) memberikan keterangan yang antara lain menyatakan bahwa Pasal 7 ayat (1) UU Perkawinan yang mengatur mengenai batas usia minimal perkawinan dianggap sebagai kesepakatan nasional yang merupakan kebijakan hukum terbuka (open legal policy) pembentuk Undang-Undang yang melihat secara bijaksana dengan berbagai macam pertimbangan dengan memperhatikan nilai-nilai yang ada pada saat itu yaitu tahun 1974; Pada perkembangannya, menyatakan bahwa usia anak adalah sejak dia lahir, bahkan pada kondisi tertentu adalah saat masih dalam kandungan, sampai dengan mencapai usia 18 tahun. Namun, pembentuk undang-undang, dalam hal ini UU Perkawinan, saat itu menentukan batas umur untuk memenuhi tujuan ideal perkawinan, bagi pria sudah mencapai umur 19 (sembilan belas) tahun dan bagi wanita sudah mencapai umur 16 (enam belas) tahun. ${ }^{3}$

Perkawinan anak memang rentan dan berpotensi menghadapi beragam permasalahan mulai dari kesehatan fisik khususnya kesehatan reproduksi, kesehatan mental, hambatan psikologis dan sosial, dan yang tak kalah pentingnya adalah berpotensi mengalami kesulitan ekonomi untuk memenuhi kebutuhan hidup yang layak yang kesemuanya dapat berujung pada perceraian dan penelantaran anak yang dilahirkan dari perkawinan tersebut serta menambah beban ekonomi bagi keluarga yang ditinggalkan atau yang ikut menanggung kebutuhan dan keberlangsungan hidup anggota keluarga yang mengalami perceraian tersebut. Adapun Penjelasan Pasal 7 ayat (1) UU Perkawinan menyatakan, "Untuk menjaga kesehatan suami-isteri dan keturunan, perlu ditetapkan batas-batas umur untuk perkawinan." Hal ini sesuai dengan tujuan luhur suatu perkawinan dan untuk menghindari beragam permasalahan sebagaimana didalilkan para Pemohon. Namun, terkait dengan norma 3 Putusan Mahkamah Konstitusi, Op. Cit., hal 2-3. yang mengatur batasan usia, Mahkamah dalam beberapa putusannya (vide Putusan Nomor 49/PUU-IX/2011 bertanggal 18 Oktober 2011, Putusan Nomor 37-39/PUU-VIII/2010 bertanggal 15 Oktober 2010, dan Putusan Nomor 15/ PUU-V/2007 bertanggal 27 November 2007) telah mempertimbangkan bahwa batasan usia minimum merupakan kebijakan hukum terbuka (open legal policy) yang sewaktu-waktu dapat diubah oleh pembentuk Undang-Undang (DPR) sesuai dengan tuntutan kebutuhan perkembangan yang ada. Hal tersebut sepenuhnya merupakan kewenangan pembentuk Undang-Undang (DPR) yang, apa pun pilihannya, tidak dilarang dan selama tidak bertentangan dengan UUD 1945.

Perkara a quo atau yang dipermasalahkan oleh para pemohon mengenai batasan usia untuk dinaikkan bagi pihak perempuan dari 16 tahun menjadi 18 tahun, dalam UUD 1945 tidak mengatur secara jelas perihal batasan usia seseorang disebut sebagai anak. Hal ini juga sama dengan pendapat dari perspektif hukum Islam yang dikemukakan oleh Ahli yang diajukan oleh para Pemohon.

Berdasarkan pertimbangan hukum di atas, telah nyata bahwa kebutuhan untuk menentukan batasan usia perkawinan khususnya untuk perempuan adalah relatif menyesuaikan dengan perkembangan beragam aspek baik itu aspek kesehatan hingga aspek sosialekonomi. Bahkan, tidak ada jaminan yang dapat memastikan bahwa dengan ditingkatkannya batas usia kawin untuk wanita dari 16 (enam belas) tahun menjadi 18 (delapan belas) tahun, akan semakin mengurangi angka perceraian, menanggulangi permasalahan kesehatan, maupun meminimalisir permasalahan sosial lainnya. Bukan berarti pula tidak perlu dilakukan upaya apa pun, terutama tindakan preventif, untuk mencegah terjadinya perkawinan usia anak yang dikhawatirkan akan menimbulkan beragam masalah sebagaimana yang didalilkan para Pemohon, yang menurut Mahkamah, beragam masalah tersebut merupakan masalah konkret yang terjadi tidak murni disebabkan dari aspek usia semata. Jikalaupun memang dikehendaki adanya perubahan batas usia kawin untuk wanita, hal tersebut bisa diikhtiarkan melalui proses legislative review yang berada 
pada ranah pembentuk Undang-Undang (DPR) untuk menentukan batas usia minimum ideal bagi wanita untuk kawin.

Pada faktanya pun, sebagaimana didalilkan para Pemohon bahwa di negara-negara lain ada pula yang menetapkan bahwa batas usia minimal bagi wanita untuk kawin adalah 17 (tujuh belas) tahun, 19 (sembilan belas) tahun, maupun 20 (dua puluh) tahun. MK justru membatasi adanya upaya perubahan kebijakan oleh negara untuk menentukan yang terbaik bagi warga negaranya sesuai dengan perkembangan peradaban dari setiap masa atau generasi, yang dalam hal ini terkait dengan kebijakan menentukan batas usia minimal kawin. Tidak tertutup kemungkinan bahwa pada saatnya nanti, dengan mendasarkan pada perkembangan teknologi, kesehatan, sosial, budaya, dan ekonomi, serta aspek lainnya, usia 18 (delapan belas) tahun bukan lagi sebagai batas usia minimum yang ideal bagi wanita untuk menikah, namun bisa saja dianggap yang lebih rendah atau lebih tinggi dari 18 (delapan belas) tahun tersebut sebagai usia yang ideal; Berdasarkan pertimbangan hukum di atas, Pasal 7 ayat (1) sepanjang frasa "16 (enam belas) tahun" UU Perkawinan tidak bertentangan dengan UUD 1945. Oleh karenanya, dalil para Pemohon a quo tidak beralasan menurut hukum.

Para Pemohon pada pokoknya mendalilkan Pasal 7 ayat (2) sepanjang kata "penyimpangan" dan frasa "pejabat lain" UU Perkawinan bertentangan dengan Pasal 1 ayat (3), Pasal 24 ayat (1), Pasal 28B ayat (1), dan Pasal 28D ayat (1) UUD 1945; Menurut para Pemohon, Pasal 7 ayat (2) sepanjang kata "penyimpangan" UU Perkawinan harus dimaknai "penyimpangan dengan alasan kehamilan di luar perkawinan"; Terhadap permohonan para Pemohon tersebut, Mahkamah berpendapat bahwa frasa "penyimpangan" a quo merupakan bentuk pengecualian yang diperbolehkan oleh hukum dan ketentuan a quo memang diperlukan sebagai "pintu darurat" apabila terdapat halhal yang bersifat memaksa atas permintaan orang tua dan/atau wali. Penyimpangan tersebut diperbolehkan berdasarkan dispensasi oleh Pengadilan atau Pejabat lain yang ditunjuk untuk itu; Adapun terhadap frasa "pejabat lain" dalam Pasal 7 ayat (2) UU Perkawinan tersebut, menurut Mahkamah, ketentuan a quo tetap dibutuhkan karena juga dapat berfungsi sebagai "pintu darurat" apabila orang tua pihak pria maupun pihak wanita dan/atau wali mereka mengalami kesulitan atau keterbatasan akses untuk menjangkau dan meminta dispensasi kepada Pengadilan. Sebagai contoh, wewenang untuk memberikan dispensasi untuk melakukan penyimpangan tersebut dapat saja diberikan oleh 15 pejabat dari Kantor Urusan Agama (KUA) atau bahkan pejabat dari kantor desa/kelurahan hingga kecamatan setempat karena alasan kemudahan akses bagi orang tua calon mempelai maupun karena pejabat tersebut memiliki kecakapan atau kompetensi untuk memberikan pertimbangan dan keputusan perihal dapat atau tidak dapatnya orang tua calon mempelai tersebut melakukan penyimpangan terhadap usia anaknya untuk melangsungkan perkawinan. Selain itu, hal ini tidak dapat dimaknai sebagai bentuk intervensi dari pihak di luar pengadilan terhadap lembaga peradilan itu sendiri karena ketentuan tersebut bersifat opsional dengan adanya kata "atau" yaitu untuk memberikan pilihan bebas bagi orang tua calon mempelai untuk menentukan akan meminta dispensasi kepada pengadilan atau pejabat lain tersebut; Berdasarkan pertimbangan hukum di atas, Pasal 7 ayat (2) sepanjang kata "penyimpangan" dan frasa "pejabat lain" UU Perkawinan tidak bertentangan dengan UUD 1945. Oleh karenanya, dalil para Pemohon a quo tidak beralasan menurut hukum.

Oleh karena alasan-asalan hukum diatas dan berdasarkan seluruh pertimbangan hukum di atas, dalil-dalil yang dimohonkan para Pemohon a quo oleh Mahkamah Konstitusi dianggap tidak beralasan menurut hukum.

\section{Analisis Hukum Islam (fiqh) terhadap Putusan Mahkamah Konstitusi Nomor 30-74/PUU-XII/2014 tentang Batas Usia Perkawinan Anak (Perempuan)}

Al-Qur'an tidak secara konkrit menentukan batas usia bagi pihak yang akan melangsungkan pernikahan. Batasan hanya diberikan berdasarkan kualitas yang harus dinikahi oleh mereka sebagaimana dalam surat an-Nisa' ayat 6 :

"Dan ujilah anak yatim itu sampai mereka cukup umur untuk kawin, kemudian 
jika menurut pendapatmu mereka telah cerdas (pandai memelihara harta), maka serahkanlah kepada mereka harta-hartanya". ${ }^{4}$

Cukup umur untuk menikah dalam ayat di atas adalah setelah timbul keinginan untuk berumah tangga, dan siap menjadi suami dan memimpin keluarga. Hal ini tidak akan bisa berjalan sempurna, jika dia belum mampu mengurus harta kekayaan.

Berdasarkan ketentuan umum tersebut, para fuqoha dan ahli undang-undang sepakat menetapkan, seseorang diminta pertanggungjawaban atas perbuatannya dan mempunyai kebebasan menentukan hidupnya setelah cukup umur (baligh). Baligh berarti sampai atau jelas, yakni anak-anak yang sudah sampai pada usia tertentu yang menjadi jelas baginya segala urusan/persoalan yang dihadapi. Pikirannya telah mampu mempertimbangkan/ memperjelas mana yang baik dan mana yang

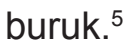

Periode baligh adalah masa kedewasaan hidup seseorang. Tanda-tanda mulai kedewasaan, apabila telah mengeluarkan air mani bagi laki-laki dan apabila telah mengeluarkan darah haid atau telah hamil bagi orang perempuan. Mulainya usia baligh dapat berbeda-beda antara seorang dengan orang yang lain, karena perbedaan lingkungan, geografis, dan sebgainya. Batas awal mulainya baligh adalah jika seorang telah berusia 12 tahun bagi laki-laki dan berusia 9 tahun bagi perempuan. Sedangkan batas akhirnya dikalangan para ulama' terdapat perbedaan pendapat. Menurut Imam Abu Hanifah yakni setelah seseorang mencapai usia 18 tahun bagi laki-laki dan telah mencapai usia 17 tahun bagi perempuan. Sedangkan menurut kebanyakan para ulama' termasuk pula sebagian ulama' Hanafiyah yaitu apabila seseorang telah mencapai usia 15 tahun baik bagi anak laki-laki maupun anak perempuan.

Pada umumnya saat itulah perkembangan

4 Departemen Agama RI, 2006, Al-Qur'an dan Terjemahnya, Diponegero, Bandung, hal. 62.

5 M. Abdul Mujieb, et.al., 1994, Kamus Istilah Fiqih, Jakarta, Pustaka Firdaus, hal. 37. kemampuan akal seseorang cukup mendalam untuk mengetahui antara yang baik dan yang buruk dan antara yang bermanfaat dan yang memandlorotkan, sehingga telah dapat mengetahui akibat-akibat yang timbul dari perbuatan yang dilakukannya. ${ }^{6}$

'Ulama madzhab Maliki, Syafi'i dan Hambali menyatakan tumbuhnya bulu-bulu ketiak merupakan bukti baligh seseorang. Mereka juga menyatakan usia baligh untuk anak laki-laki dan perempuan 15 (lima belas) tahun. Sedangkan Imam Hanafi menolak bulu-bulu ketiak sebagai bukti baligh seseorang, sebab bulu-bulu ketiak itu tidak ada bedanya denga bulu-bulu lain yang ada pada tubuh. Imam Hanafi menetapkan batas maksimal usia baligh anak laki-laki adalah delapan belas tahun dan minimalnya dua belas tahun, sedangkan usia baligh anak perempuan maksimal 17 (tujuh belas) tahun dan minimalnya 9 (sembilan) tahun.

Ukasyah Athibi dalam bukunya Wanita Mengapa Merosot Akhlaknya, menyatakan bahwa seseorang dianggap sudah pantas untuk menikah apabila dia telah mampu memenuhi syarat-syarat berikut, yaitu 1 . Kematangan jasmani; 2. Kematangan finansial/keuangan; 3. Kematangan perasaan. ${ }^{7}$

Masalah kematangan fisik dan jiwa seseorang dalam konsep Islam tampaknya lebih ditonjolkan pada aspek fisik. Hal ini dapat dilihat dari pembebanan hukum bagi seseorang (mukallaf). Dalam IImu Fiqh, tanda-tanda baligh atau dewasa ada tiga, yaitu:

1. Menurut ulama' Hanafiyah genap usia 15 (lima belas) tahun bagi laki-laki dan perempuan.

2. Mimpi keluar sperma (mani) bagi laki-laki.

3. Haid (menstruasi) bagi perempuan bila sudah berusia sembilan tahun. ${ }^{8}$

6 Proyek Pembinaan Prasarana dan Sarana Perguruan Tinggi Agama/IAIN Jakarta, Direktorat Jendral Pembinaan Kelembagaan Agama Islam Departemen Agama, 1985, IImu Fiqh, jiid II, Jakarta, hal. 3-4.

7 Ukasyah Athibi, 1998, Wanita Mengapa Merosot Akhlaknya, Jakarta, Gema Insani, hal. 351-352.

8 Salim Bin Smeer Al Hadhrami, 1994, Safinatun Najah, terj. Abdul Kadir Aljufri, Surabaya, Mutiara Ilmu, hal. 3-4. 
Sedangkan dalam kitab Fathul Mu'in usia baligh yaitu setelah sampai batas tepat 15 tahun dengan dua orang saksi yang adil, atau setelah mengeluarkan air mani atau darah haid. Kemungkinan mengalami dua hal ini adalah setelah usia sempurna 9 tahun. Selain itu tumbuhnya rambut kelamin yang lebat sekira memerlukan untuk dipotong dan adanya rambut ketiak yang tumbuh melebat. ${ }^{9}$

Pendapat para ulama tersebut merupakan ciri-ciri pubertas yang hanya berkaitan dengan kematangan seksual yang menandai awal kedewasaan. Kalau kedewasaan merujuk pada semua tahap kedewasaan, maka pubertas hanya berkaitan dengan kedewasaan seksual. Kedewasaan seseorang akan sangat menentukan pola hidup dan rasa tanggung jawab dalam berumah tangga untuk menghadapi kehidupan yang penuh dengan problema yang tidak pernah dihadapinya ketika orang tersebut belum kawin. Kedewasaan juga merupakan salah satu unsur yang mendorong terbentuknya keluarga sakinah, mawaddah warahmah.

Pentingnya lembaga perkawinan maka seseorang yang akan melaksanakan perkawinan harus mempunyai persiapan yang matang dalam segala bidang. Persiapan ini berkaitan dengan kedewasaan seseorang, tidak dapat diragukan, kehidupan pada masa sekarang lebih sulit dibanding pada zaman dahulu. Datangnya ihtilam (mimpi basah) sering tidak sejalan dengan matangnya pikiran seseorang yang telah memiliki kedewasaan berfikir. Seharusnya dalam menentukan anak cukup umur adalah kedewasaannya secara jiwa, bukan dari banyaknya umur dan tanda-tanda fisik (tubuh).

3. Usia Perkawinan menurut hukum Islam berkaitan dengan Putusan Nomor 30 dan 74/PUU-XII/2014 tentang Batas Usia Perkawinan Anak (Perempuan)

Tujuan perkawinan adalah untuk mendapatkan ketenangan hati (sakinah). Seorang laki-laki dan seorang perempuan yang hidup dalam perkawinan akan mendapatkan ketenangan. Sebelumnya seorang laki-laki atau seorang perempuan dalam keadaan sendiri mengalami

9 Aliy As'ad, 1979, Fathul Mu'in Jilid II, terj. Moh. Tolchah Mansor, Menara, Kudus, hal. 232-233 gejolak asmara yang tidak tersalurkan, karena itu mereka tidak memperoleh ketenangan. Sakinah itu dapat lestari manakala kedua belah pihak yang berpasangan itu memelihara mawaddah, yaitu kasih sayang yang terjalin antara kedua belah pihak tanpa mengharapkan imbalan (pamrih) apapun melainkan semata-mata karena keinginannya untuk berkorban dengan memberikan kesenangan kepada pasangannya. Oleh karena itu, mawaddah bersifat altruistik, bukan egoistik. Sikap egoistik, yaitu hanya ingin mendapatkan segala hal yang menyenangkan bagi diri sendiri, sekalipun akan menyakitkan hati pasangannya, akan berarti memutuskan mawaddah. Dengan terputusnya mawaddah dengan sendirinya sakinah pun tidak terpelihara lagi. Selain keharusan memelihara mawaddah, sakinah pun akan terwujud dan terpelihara jika suami dan isteri memelihara rahmah, yaitu saling memberi dan menerima atas dasar kasih sayang dalam kedudukannya yang berbeda, yakni sebagai suami maupun isteri yang samasama mempunyai kelebihan dan kekurangannya masing-masing. ${ }^{10}$

Prof. Muhammad Quraish Shihab berpendapat selaku ahli hukum Islam yang dihadirkan dalam sidang perkara Nomor 30 dan 74/PUU-XII/2014 tentang Batas Usia Perkawinan Anak (Perempuan), menyatakan bahwa,

"...kitab suci AI Quran, demikian juga Sunnah Nabi, tidak menetapkan usia tertentu. Ini sejalan dengan hikmah llahi yang tidak mencantumkan rincian sesuatu dalam kitab suci menyangkut hal-hal yang dapat mengalami perubahan. Yang dirincinya hanya hal-hal yang tidak terjangkau oleh nalar seperti persoalan metafisika atau hal-hal yang tidak mungkin mengalami perubahan dari sisi kemanusiaan, seperti misalnya, ketetapannya mengharamkan perkawinan anak dengan ibunya atau dengan ayahnya karena di situ selama manusia normal, tidak mungkin ada birahi terhadap mereka. Karena tidak adanya ketetapan yang pasti dari kitab suci, maka ulama-ulama Islam berbeda pendapat tentang usia tersebut bahkan ada di antara masyarakat Islam yang justru melakukan revisi dan perubahan menyangkut

10 Perkara Nomor 12/PUU-V/2007 tentang permohonan pengujian UU Perkawinan, bertanggal 3 Oktober 2007. 
ketetapan hukum tentang usia tersebut. Ini untuk menyesuaikan dengan perkembangan masyarakat dan kebutuhannya". ${ }^{11}$

Hukum Islam (fiqh) dapat berubah sesuai dengan keadaan atau situasi dan kondisi yang mengitarinya, hal ini yang biasa disebut dengan kontekstualisasi hukum Islam. Kontekstualisasi hukum Islam setidaknya dipengaruhi 2 hal, yang pertama adalah adanya kaidah fiqh dalam bidang mu'amalah yang menyatakan bahwa "hukum asal semua perbuatan adalah diperbolehkan hingga ada hukum yang melarangnya", kedua adalah adanya hadist yang menyatakan bahwa "kamu lebih mengetahui urusan duniamu". Pada hadist tersebut menunjukkan bahwa umat Islam dalam konteks tertentu dipersilahkan untuk menemukan solusi masalah-masalah yang dihadapi berdasarkan pandangan-pandangan atau ijtihad hukum sendiri. Melalui hadist tersebut juga dapat diartikan bahwa Islam juga menerima pandangan-pandangan baru, demi merespon perubahan sosial yang terus terjadi, seiring perubahan tatanan masyarakat, ekonomi, industrialisasi, perkembangan ilmu pengetahuan, teknologi dan hubungan internasional dan lain sebagainya. ${ }^{12}$

\section{Simpulan}

1. Usia Perkawinan secara yuridis normatif menurut Putusan Nomor 30 dan 74/PUUXII/2014 tentang Batas Usia Perkawinan Anak (Perempuan), menurut penilaian Mahkamah Konstitusi:

Pertama, berkaitan dengan permohonan yang menyangkut uji materi Pasal 7 ayat (1), Mahkamah justru membatasi adanya upaya perubahan kebijakan oleh negara untuk menentukan yang terbaik bagi warga negaranya sesuai dengan perkembangan peradaban dari setiap masa atau generasi, yang dalam hal ini terkait dengan kebijakan menentukan batas usia minimal kawin. Tidak tertutup kemungkinan bahwa pada saatnya nanti, dengan mendasarkan pada perkembangan teknologi, kesehatan, sosial,

11 Putusan Mahkamah Konstitusi, Op. Cit., hal 6364.

12 Mahsun Fuad, 2004, Hukum Islam Indonesia (Dari Nalar Partisipatoris Hingga Emansipatoris), Yogyakarta, LKiS, hal. 197-198. budaya, dan ekonomi, serta aspek lainnya, usia 18 (delapan belas) tahun bukan lagi sebagai batas usia minimum yang ideal bagi wanita untuk menikah, namun bisa saja dianggap yang lebih rendah atau lebih tinggi dari 18 (delapan belas) tahun tersebut sebagai usia yang ideal; Berdasarkan pertimbangan hukum di atas, Pasal 7 ayat (1) sepanjang frasa "16 (enam belas) tahun" UU Perkawinan tidak bertentangan dengan UUD 1945. Oleh karenanya, dalil para Pemohon a quo tidak beralasan menurut hukum.

Kedua, mengenai uji materi Pasal 7 ayat (2) sepanjang kata "penyimpangan" UU Perkawinan harus dimaknai "penyimpangan dengan alasan kehamilan di luar perkawinan"; Terhadap permohonan para Pemohon tersebut, Mahkamah Konstitusi berpendapat bahwa frasa "penyimpangan" a quo merupakan bentuk pengecualian yang diperbolehkan oleh hukum dan ketentuan a quo memang diperlukan sebagai "pintu darurat" apabila terdapat hal-hal yang bersifat memaksa atas permintaan orang tua dan/ atau wali. Penyimpangan tersebut diperbolehkan berdasarkan dispensasi oleh Pengadilan atau Pejabat lain yang ditunjuk untuk itu; Adapun terhadap frasa "pejabat lain" dalam Pasal 7 ayat (2) UU Perkawinan tersebut, menurut Mahkamah, ketentuan a quo tetap dibutuhkan karena juga dapat berfungsi sebagai "pintu darurat" apabila orang tua pihak pria maupun pihak wanita dan/atau wali mereka mengalami kesulitan atau keterbatasan akses untuk menjangkau dan meminta dispensasi kepada Pengadilan. Sebagai contoh, wewenang untuk memberikan dispensasi untuk melakukan penyimpangan tersebut dapat saja diberikan oleh 15 pejabat dari Kantor Urusan Agama (KUA) atau bahkan pejabat dari kantor desa/kelurahan hingga kecamatan setempat karena alasan kemudahan akses bagi orang tua calon mempelai maupun karena pejabat tersebut memiliki kecakapan atau kompetensi untuk memberikan pertimbangan dan keputusan perihal dapat atau tidak dapatnya orang tua calon mempelai tersebut melakukan penyimpangan terhadap usia anaknya untuk melangsungkan perkawinan. Selain itu, hal ini tidak dapat dimaknai sebagai bentuk intervensi dari pihak di luar pengadilan terhadap lembaga peradilan itu sendiri karena ketentuan tersebut 
bersifat opsional dengan adanya kata "atau" yaitu untuk memberikan pilihan bebas bagi orang tua calon mempelai untuk menentukan akan meminta dispensasi kepada pengadilan atau pejabat lain tersebut; Berdasarkan pertimbangan hukum di atas, Pasal 7 ayat (2) sepanjang kata "penyimpangan" dan frasa "pejabat lain" UU Perkawinan tidak bertentangan dengan UUD 1945. Oleh karenanya, dalil para Pemohon a quo tidak beralasan menurut hukum.

2. Usia Perkawinan menurut hukum Islam berkaitan dengan Putusan Nomor 30 dan 74/
PUU-XII/2014 tentang Batas Usia Perkawinan Anak (Perempuan), bahwa dalam kitab suci Al Quran, demikian juga Sunnah Nabi, tidak menetapkan usia tertentu. Hal ini disebebakan karena tidak adanya ketetapan yang pasti dari kitab suci dan juga hadist, maka ulama-ulama Islam, para fuqoha berbeda pendapat tentang usia perkawinan tersebut, dan justru hukum Islam memberi ruang adanya perubahan jika ternyata hukum Islam dalam masalah tertentu sudah tidak sesuai perkembangan zaman (hukum Islam bersifat kontekstual).

\section{Daftar Pustaka}

Aliy As'ad, 1979, Fathul Mu'in Jilid II, terj. Moh. Tolchah Mansor, Menara, Kudus.

Departemen Agama RI, 2006, Al-Qur'an dan Terjemahnya, Bandung, Diponegero.

Gus Arifin, 2010, Menikah Untuk Bahagia (Fiqh Tentang Pernikahan Dan Kamasutra Islami), Jakarta, PT Elex Media Komputindo.

Husein Muhammad, 2007, Fiqih Perempuan (Refleksi Kiai atas Wacana Agama dan Gender), Yogyakarta, LKiS.

M. Abdul Mujieb, et.al., 1994, Kamus Istilah Fiqih, Jakarta, Pustaka Firdaus.

Mahsun Fuad, 2004, Hukum Islam Indonesia (Dari Nalar Partisipatoris Hingga Emansipatoris), Yogyakarta, LKiS.

Muhammad bin Ismail Abu Abdillah Al-Bukhari, 1987, Al-Jaami'us Shahih Al-Mukhtashar,, Beirut , Dar Ibnu Katsir.

Proyek Pembinaan Prasarana dan Sarana Perguruan Tinggi Agama/IAIN Jakarta, Direktorat Jendral Pembinaan Kelembagaan Agama Islam Departemen Agama, 1985, Ilmu Fiqh, jiid II, Jakarta.

Salim Bin Smeer Al Hadhrami, 1994, Safinatun Najah, terj. Abdul Kadir Aljufri, , Surabaya Mutiara IImu.

Ukasyah Athibi, 1998, Wanita Mengapa Merosot Akhlaknya, Jakarta, Gema Insani.

Yoga Anggoro, 2007, Undang-Undang Perkawinan Nomor 1 Tahun 1974 dan Undang-Undang 23 Tahun 2004 Tentang Penghapusan Kekerasan dalam Rumah Tangga, Jakarta, Transmedia Pustaka.

Undang-Undang Dasar Negara Republik Indonesia Tahun 1945.

Perkara Nomor 12/PUU-V/2007 tentang permohonan pengujian UU Perkawinan, bertanggal 3 Oktober 2007.

Putusan Mahkamah Konstitusi Nomor 30-74/PUU-XII/2014. 